\title{
Morels for Dinner
}

\author{
By RAY PETERSON, Tofield, Alberta
}

A bright, warm day in late May, two small, excited sons for company and time to spare for a walk in the woods - a perfect formula for an enjoyable time.

"What's the pail for, Daddy?" Michael asked, as we started off.

"Morels," I said. "Mmmmm, I can almost taste them, already."

"Look!" Colin said, pointing with excitement. "Yellow butterflies. One, two, three, six, ten," and the enthusiasm of a three year old, minus the botherscme restraints of accuracy, led him to an impressive total.

"There's four," Michael said, stoutly asserting his two-year seniority. "And they are called Yellowtails." ly.

"Swallow-tails," I corrected gent-

We crossed a meadow that had been flooded last year and was now dry. A densely-piled carpet of bluegrass, soft and springy underfoot, was taking hold again. On a south slope above the meadow a line of white poplar trees showed tops that were bare of leaves, some of them nearly halfway down. The brown, dead buds gave stark evidence of the damage that the spring's vicious lapse into winter had done.

Huge, black ground beetles seemed to be scurrying everywhere. Michael jumped and yelled as an extra big fellow crawled over his shoe.

"There is not anything to be nervous about," I assured him. "See! the beetle is afraid of you and it is trying to hide under that pile of dead leaves."

"Oh!" Michael said, his fear suddenly gone.

$\mathrm{Our}$ search of lightly-wooded slopes which were usually good morel grounds gave us no reward. The intense dry weather that had followed the spring's sudden, dramatic runoff, was responsible. We shifted to moister ground at the base of a long, heavily-timbered slope. There, on the borderline where slough and trees met, we found our morels.

Long-stemmed morels, many of them too old to use for food, were growing around willow clumps and into the slough itself. A bit further

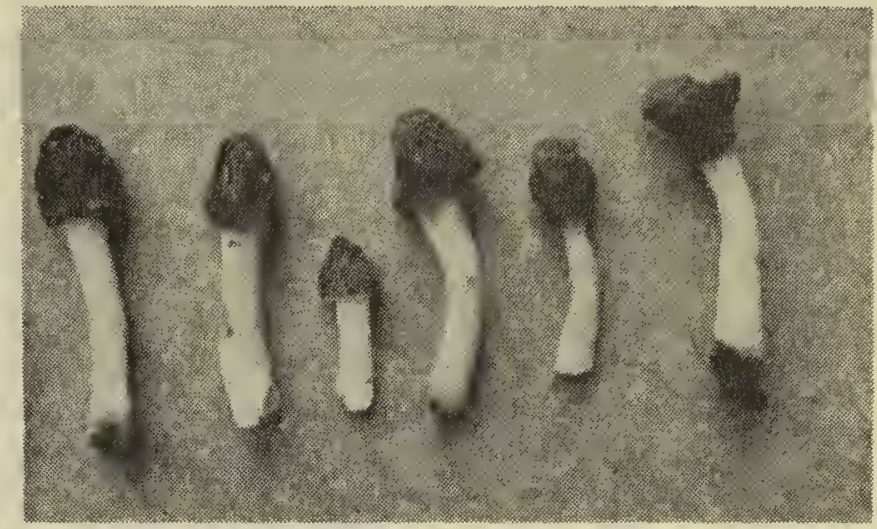

LONG-STEMMED MOREL

on in the woods were the pointed, grooved heads of cone-shaped morels, our favorite mushrooms. The boys, once they became accustomed to spotting the morels, were quick pickers. Soon, the pail was full. So too, at our expense, were many of the mosquitoes that zoomed up from the deep shade in humming squadrons.

We turned for home. I showed the boys a Mallard's nest. It was built in a Magpie nest, about eight feet from the ground, and was the first one that $\mathrm{I}$ had ever discovered in a tree.

From a tree top, a brilliantly-clad minstrel, an oriole, whistled a lilting call, and a pair of crows flew lazily by. Just back from the South, a Catbird murmured a plaintive cry; and a chipmunk shittered mischievously as he scampered over an old brushpile.

"W ho a! Daddy," Colin cried. "Michael and I want to pick some flowers for Mummy." Soon, each of them had a bouquet of dandelions, white violets, and everlastings. What matter if many of the flowers were a bit bent and bedraggled! Mummy would be thrilled with their blossoms.

We trudged up the last hill towards home, a man and two tired, but happy children, with a pail of morels and some wild flowers. This was an outing I would always remember for I had caught a glimpse of Nature as seen through the eyes of two small boys as well as through my own. And if this hike had helped to further their love for Nature, then this day had a touch of greatness, too. 